\title{
Orvosi rehabilitációs kezelésben részesülő betegek orális egészségügyi állapotának vizsgálata
}

\author{
Orsós Mercédesz dr. - Moldvai Júlia dr. \\ Kivovics Péter dr. - Németh Orsolya dr. \\ Semmelweis Egyetem, Fogorvostudományi Kar, Fogászati és Szájsebészeti Oktató Intézet, Budapest
}

Bevezetés: A világon több mint 1 milliárd ember, ebből Magyarországon a 2011. évi népszámlálás alapján 500000 ember él valamilyen fogyatékkal. Ezek az emberek veszélyeztetett csoportba tartoznak fogászati szempontból is, hiszen a funkcióveszteség következményeként a szájhigiéniás rutin és rendszeres fogorvosi kontroll nehezített. 2015 őszén a Fogászati és Szájsebészeti Oktató Intézet és az Országos Orvosi Rehabilitációs Intézet által közösen múködtetett fogorvosi rendelő került átadásra, hogy a rehabilitáció alatt állók szájhigiéniás felmérése, dentális és szájhigiéniás rehabilitációja is megtörténjen.

Célkituzés: 608, rehabilitációs kezelés alatt álló beteg fogászati állapotának felmérése és sztomatoonkológiai szűrése, valamint szükség esetén kezelése történt meg. Ezáltal átfogó képet kapunk a rehabilitációra szoruló, fogyatékossággal élő betegek szájüregi állapotáról.

Módszer: A fogorvosi klinikai vizsgálat WHO-ajánlás alapján történt: a DMF-T-számot, a fogászati ellátottságot, a szájnyálkahártyán látható elváltozásokat mértük fel. A 20 kérdésből álló kérdőív segítségével a szájhigiéniás rutinról, a fogorvoshoz járás gyakoriságáról, az étkezési szokásokról, a káros szenvedélyekről és a szociális háttérről nyertünk adatokat.

Eredmények: Az ellátottság csupán alacsony szintjét figyelhetjük meg. A hiányzó fogak száma magas, viszont a fogazat pótoltsága alacsony. A DMF-T-szám 20,5, ebből a D-T = 2,6, M-T = 11,2, F-T = 6,7. A páciensek fogászati és szájnyálkahártya-elváltozások okozta panaszai minimálisak az általános fogászati állapotukhoz képest, nagy részük nem észlelt fogfájást az előző 12 hónapban. Az utolsó fogorvosi vizsgálat időpontja a betegek többségénél meghaladja a 12 hónapot.

Következtetések: A fogyatékkal élő betegek szájhigiéniás állapota rossz, ennek oka, hogy fogászati terápiájuk, gondozásuk a mindennapi gyakorlatban nem megoldott.

Orv Hetil. 2018; 159(52): 2202-2206.

Kulcsszavak: fogyatékosság, dentális rehabilitáció, szájhigiénia, funkcióvesztés, epidemiológiai vizsgálat

\section{Oral health related quality of life of patients undergoing physical medicine and rehabilitation}

Introduction: More than 1 billion people in the world live with some form of disability. According to the 2011 census in Hungary, their number can be around 500 000. These people are considered as a vulnerable group even from a dental point of view, since the loss of function makes regular oral hygienic routine and dentistry control more difficult. In 2015, The Department of Community Dentistry and The National Institute of Medical Rehabilitation started to operate together a dental office to examine the dental and oral hygiene condition of the inpatients and to make their oral rehabilitation.

Aim: A total of 608 patients have gone through a full dental examination including a stomato-oncological screening. From this we gathered comprehensive information on the oral health of patients currently undergoing rehabilitation and living with disabilities.

Method: This study was approved by the Medical Research Council. Clinical examinations were done on the basis of the recommendation by WHO. We analysed the DMF-T values, restorative index, periodontal status and lesions of the oral mucosa. From a survey of 20 questions we asked about oral hygiene practices, toothbrushing frequency, last visit to a dentist, eating habits, addictions and social background.

Results: The patients had poor oral hygiene. The number of lost teeth is high, but the prosthetic care is not satisfying. The DMF-T value was 20.5, from this $\mathrm{D}-\mathrm{T}=2.6, \mathrm{M}-\mathrm{T}=11.2, \mathrm{~F}-\mathrm{T}=6.7$. The patients' complaints about dental and 
oral mucosal lesions are minimal compared to their general dental condition. A majority of them did not experienced toothaches in the last 12 months. The last dental checkup in the case of most patients exceeds 12 months.

Conclusions: The oral hygiene of patients living with some form of disability is poor since their daily oral hygiene routine and care in practice are not solved.

Keywords: disability, dental rehabilitation, oral hygiene, loss of function, epidemiological study

Orsós M, Moldvai J, Kivovics P, Németh O. [Oral health related quality of life of patients undergoing physical medicine and rehabilitation]. Orv Hetil. 2018; 159(52): 2202-2206.

(Beérkezett: 2018. május 29.; elfogadva: 2018. július 11.)

\begin{abstract}
Rövidítések
BNO = Betegségek Nemzetközi Osztályozása; DMF-T = $($ decayed, missing, filled tooth) szuvas, hiányzó, tömött fogak; FSZOI = Fogászati és Szájsebészeti Oktató Intézet; MTA Cloud = a Magyar Tudományos Akadémia felhőszolgáltatása; MTA SZTAKI = Magyar Tudományos Akadémia, Számítástechnikai és Automatizálási Kutatóintézet; MTA WIGNER FK = Magyar Tudományos Akadémia, Wigner Fizikai Kutatóközpont; OORI = Országos Orvosi Rehabilitációs Intézet; RI = (restorative index) a fogorvosi ellátás indikátora; WHO = (World Health Organization) Egészségügyi Világszervezet
\end{abstract}

A 2011. évi népszámláláskor hazánkban közel félmillió ember - a társadalom 4,6\%-a - élt valamilyen fogyatékkal [1]. Számuk folyamatosan növekszik, köszönhetően az elöregedésnek és az egyre nagyobb számban előforduló krónikus megbetegedéseknek, mint a diabetes, a cardiovascularis és mentális betegségek [2]. Az ezen betegségek következményei, illetve baleset okozta károsodás miatt rehabilitációra szoruló betegek önállóságukat részben vagy egészében elvesztették. Állapotuk súlyosságának függvényében különböző mértékű hátrányt szenvednek a napi rutin fenntartásában [3]. A fogászati ellátás szempontjából a veszélyeztetett és speciális ellátást igénylő páciensek közé tartoznak [4]. Magyarország a 2014 és 2020 közötti időszakban 12 milliárd forint fejlesztési forrást használhat fel különböző célokra, köztük akadálymentesítésre az Európai Unió és a hazai költségvetés támogatásával a Széchenyi 2020 program keretén belül. Elérhető az Emberi Erőforrások Minisztériuma által kiadott lista is a fogyatékkal élók speciális egészségügyi ellátására szóló finanszírozási szerződéssel múködő fogászatokról $[5,6]$. Viszont az akadálymentesített fogorvosi rendelő elérése nehezített lehet, vagy ha ez megtörténik is, a betegek gyakran nem kapják meg a megfelelő beavatkozást, mert a fogorvosok félnek a speciális ellátást igénylő páciensek kezelésétől, vagy nem rendelkeznek kelló tapasztalattal. A fogorvosképzés curriculumának egyelőre nem része a fogyatékkal élő betegek ellátásának ismerete. Egy az OORI által végzett vizsgálatból kiderült, hogy a rehabilitációs alapismeretek az általános orvosok körében sem elégségesek [7]. A páciensek szájhigiéniás edukációja is hiányos, ennek egyik oka, hogy ezen betegcsoport szájhigiéniás állapotáról és fogazati statusáról nem áll rendel- kezésre adat, fogorvosi prevenciójáról, vizsgálatáról, ellátásáról és utánkövetéséról még nem születtek irányelvek és protokollok. 2015 őszén a Fogászati és Szájsebészeti Oktató Intézet és az Országos Orvosi Rehabilitációs Intézet által együttes erőkkel múködtetett fogorvosi rendelő került átadásra. Az FSZOI munkatársainak segítségével a rehabilitálni kívánt betegek olyan átfogó programban tudnak részt venni, melyben a szájüregi egészségi állapotuk vizsgálata is megtörténik. A páciensek megmaradt képességeit felmérve, eredményeink segítségével új fogászati prevenciós modelleket tervezünk létrehozni, melyek elősegítik a páciens adott körülményeihez való alkalmazkodást. Mivel a rehabilitáció interdiszciplináris teammunka, fogászati kompenzatorikus fejlesztési modellekre tennénk majd ajánlatokat, melyekkel a szájhigiéniájuk javulása megvalósulhatna.

\section{Módszer}

608, fogyatékkal élő páciens fogazati állapotának vizsgálatára került sor, melyet két, epidemiológiailag standardizált fogorvos végzett; minden beteg az OORI valamelyik fekvőosztályán bent fekvő, aktív rehabilitációs kezelés alatt álló személy volt. A vizsgálathoz írásos beleegyezésüket adták a résztvevők, kiskorúság esetén a szülők beleegyezését kértük. A felmérés 2016. 04. 05. és 2018. 01. 20. között, a Magyar Etikai Bizottság (Egészségügyi Tudományos Tanács Tudományos és Kutatásetikai Bizottság) jóváhagyásával zajlott. Az engedély száma: ETT TUKEB 4913/2016/EKU.

A fogászati állapotot a WHO által ajánlott eszközökkel (standard fogászati tükör és szonda) és 20 kérdésből álló kérdőív segítségével mértük fel: a DMF-T-számot, a fogászati ellátottságot, a szájnyálkahártyán látható elváltozásokat vizsgáltuk. A DMF-T-szám egy kvantitatív mérőszám, mely a szuvas (decayed), a hiányzó (missing) és a tömött (filled) fogak (tooth) számát határozza meg [8]. A fogorvosi ellátás indikátora, a Dental Care Level (restorative index, RI) megmutatja az ellátott és az ellátatlan szuvas fogak arányát. A következő formulával számoljuk ki: RI = $\mathrm{F} /(\mathrm{D}+\mathrm{F}) \times 100$, ahol az F a tömött maradó fogak száma, a D + F a szuvas és tömött maradó fogak összege [9].

A szájhigiéniás szokásokról, a leggyakrabban fogyasztott ételekről, a függőséget okozó szerekrôl és a szociodemográfiai háttérről is tájékozódtunk (Kérdôíp) $[2,10]$. 
A betegek teljes orvosi dokumentációja rendelkezésünkre állt, melyből BNO-kódok alapján az alapbetegségekrôl és a rehabilitáció okáról nyertünk adatokat.

A szüréseket digitálisan dolgoztuk fel az MTA Wigner FK informatikusaival együtt kifejlesztett szoftver segítségével, mely tableten, applikáció formájában érhető el. A készülékről az adatok közvetlenül az MTA SZTAKI és az MTA WIGNER FK Adatközpont közös munkája nyomán létrejött MTA Cloudba kerülnek, ahonnan bármikor letölthetők [11].

\section{Statisztikai analízis}

A nyert adatokat a Statistical Package for the Social Sciences (SPSS) 23.0 verzió (SPSS Inc., Chicago, IL, Amerikai Egyesült Államok) 'case summary' programja segítségével elemeztük. A betegek lakcímét a Google Maps API segítségével, R-kódot használva, automatizálva megkerestettük az egyes címekhez kapcsolható pontos GPS-koordinátákat. A vizualizációhoz a Tableau-alkalmazás publikus változatát használtuk, mely segített a lakcímek megjelenítésében.

\section{Eredmények}

Az OORI 9 fekvőosztályáról összesen 608 beteg fogászati szürése történt meg: Agysérültek Rehabilitációs Osztálya (87 fó), Amputációs Sebészeti Osztály (9 fơ), Baleseti Mozgássérültek Rehabilitációs Osztálya (60 fő), Gerincvelősérültek Rehabilitációs Osztálya (87 fő), Hemiplegia Rehabilitációs Osztály (91 fó), Ortopédiai Osztály (72 fó), Pszichoszomatikus és Pszichoterápiás Rehabilitációs Osztály (13 fó), Szeptikus Mozgásszervi Rehabilitációs Osztály (88 fő), Vegyes Profilú Mozgásszervi Rehabilitációs Osztály (101 fó).

A nemek közötti megoszlás egyenletes: nő : férfi $=297$ fó $(48,8 \%)$ : 311 fö $(51,2 \%)$. A betegek életkora 15 és 94 év közötti, korcsoport szerinti felosztásuk: 15-24 év (27 fó), 25-49 év (159 fó), 50-64 év (165 fó), 65-79 év (209 fó), 80-94 év (48 fö) (1. ábra). Az átlagéletkor 59 év volt. A demográfiai adatok alapján 260 fó $(42,8 \%)$ rendelkezik budapesti, míg 348 fó $(57,2 \%)$ vidéki állandó lakcímmel. A DMF-T-szám 20,5, ebból a D-T = 2,6, $\mathrm{M}-\mathrm{T}=11,2, \mathrm{~F}-\mathrm{T}=6,7$. Az ellátottsági szint alacsony, a restorative index értéke: $\mathrm{RI}=67,41$. A betegek 68,9\%-a nem érzett orofacialis eredetű fájdalmat az elmúlt 12 hónapban (1. táblázat). Szájnyálkahártya-elváltozást 196 betegnél észleltünk. A leggyakrabban decubitus, aphta és stomatitis volt a diagnózis. Az ajánlott féléves fogászati kontrollon a betegek $28,8 \%$-a vett részt, viszont $16,3 \%$ 5 évnél régebben járt fogorvosnál (2. ábra). A rehabilitáció alatt álló betegek 57,24\%-a mos fogat naponta kétszer vagy akár többször, 30,59\% napi egyszer tisztítja fogait. A felmérés során az esetek 2,14\%-ában találkoztunk olyan betegekkel, akik soha nem mostak fogat (2. táblázat). A megfelelő szájhigiénia fenntartásához a legtöbben hagyományos fogkefét (88\%) és fluoridtartalmú

\section{Részlet a kérdőívben feltett kérdésekből}

Milyen gyakran mos fogat?

$\square$ Soha

$\square$ Egyszer egy hónapban

$\square$ 2-3 alkalommal egy hónapban

$\square$ Egyszer egy héten

$\square$ 2-6 alkalommal egy héten

$\square$ Naponta

$\square$ Naponta kétszer, vagy többször

Fájt a foga az elmúlt 12 hónapban?

$\square$ Igen

$\square$ Nem

$\square$ Nem tudom

Fogai tisztítására a felsoroltak közül melyiket használja?

$\square$ Hagyományos fogkefe

$\square$ Elektromos fogkefe

$\square$ Fluorid tartalmú fogkrém

$\square$ Fogselyem

$\square$ Szájöblögető

$\square$ Fa fogpiszkáló

$\square$ Müanyag fogpiszkáló

Mikor volt az utolsó fogászati szürése?

$\square$ Kevesebb mint 6 hónapja

$\square$ 6-12 hónapja

$\square$ Több mint 1 , de kevesebb mint 2 éve

$\square 2$ vagy több, de kevesebb mint 5 éve

$\square 5$ évnél régebben

$\square$ Soha nem álltam fogászati kezelés alatt

Milyen gyakran fogyaszt friss gyümölcsöt?

$\square$ Többször egy nap

$\square$ Minden nap

$\square$ Többször egy héten

$\square$ Egyszer egy héten

$\square$ Többször egy hónapban

$\square$ Ritkán

Milyen gyakran fogyaszt magas szénhidrát tartalmú ételt?

$\square$ Többször egy nap

$\square$ Minden nap

$\square$ Többször egy héten

$\square$ Egyszer egy héten

$\square$ Többször egy hónapban

$\square$ Ritkán

Milyen gyakran dohányzik?

$\square$ Naponta

$\square$ Többször egy héten

$\square$ Hetente

$\square$ Többször egy hónapban

$\square$ Néha

$\square$ Soha

Milyen gyakran fogyaszt alkoholt?

$\square$ Naponta

$\square$ Többször egy héten

$\square$ Hetente

$\square$ Többször egy hónapban

$\square$ Néha

$\square$ Soha 


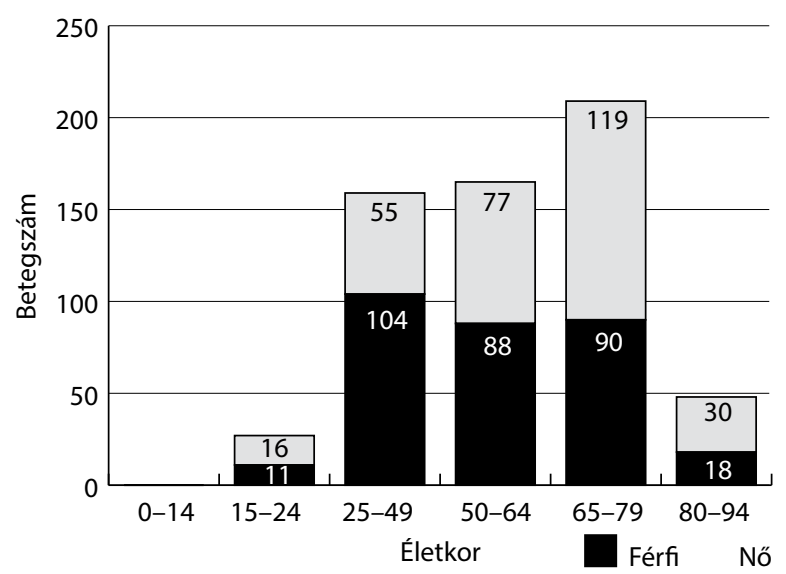

1. ábra

A vizsgált személyek korcsoport és nem szerinti megoszlása $(\mathrm{n}=608)$

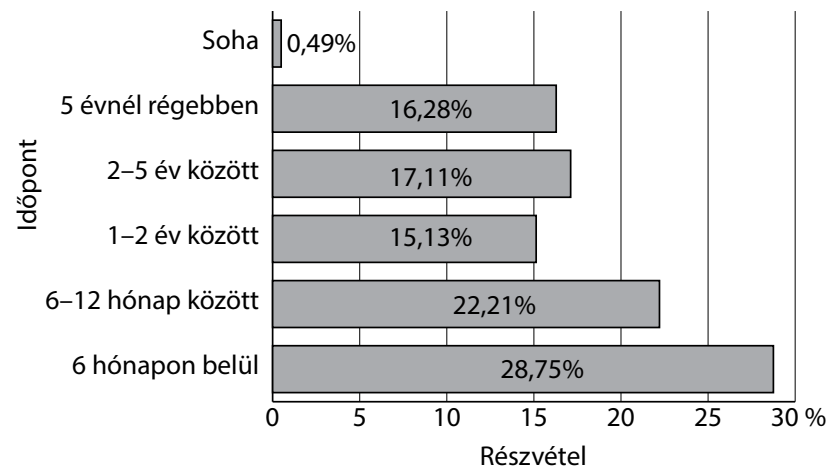

2. ábra

Az utolsó fogorvosi vizsgálaton való részvétel százalékos megoszlása $(\mathrm{n}=608)$

fogkrémet $(88,8 \%)$ használnak. A fogmosás mellé ajánlott kiegészítő eszközök közül a fogselymet 12,7\%, míg szájöblögetôt $\mathbf{5 2} \%$ használ (3. táblázat). A táplálkozási szokásokat nézve friss gyümölcsöt $67,4 \%$ fogyaszt napi rendszerességgel, míg magas szénhidráttartalmú ételeket $37,7 \%$ vesz magához naponta. A kérdőíveket kiértékelve elmondhatjuk, hogy a megvizsgált betegek 80,9\%-a nem, míg 19,1\%-a dohányzik. A dohányzó betegeknél külön vettük a kérdőív alapján a naponta, hetente egyszer vagy többször, illetve a havonta dohányzó betegek számát. Az általunk fontosnak ítélt naponta rágyújtó páciensek a megvizsgált betegek 16,8\%-a. Az alkoholfogyasztásról elmondható, hogy a betegek 17,37\%-a fogyaszt alkoholt, a betegek 82,63\%-a azonban az elózó 30 napban nem ivott alkoholt.

\section{Megbeszélés}

Az OORI az ország bármely területéról fogad betegeket, székhelye Budakeszi; ez lehet az oka annak, hogy a bent fekvő páciensek túlnyomó része budapesti címmel rendelkezik. A DMF-T-számokat nézve a hiányzó fogak száma magas, mivel a megtartó kezelés helyett esetükben a fogeltávolítást részesítették előnyben, viszont a fogazat
1. táblázat | Fogfájás az elmúlt 12 hónapban $(\mathrm{n}=608)$

\begin{tabular}{ll}
\hline Válaszok & Fájt a foga az elmúlt 12 hónapban? $(\mathrm{n}=608)$ \\
\hline Igen & $176(28,9 \%)$ \\
Nem & $419(68,9 \%)$ \\
Nem tudom & $13(2,1 \%)$ \\
\hline
\end{tabular}

2. táblázat |A fogmosás gyakorisága $(\mathrm{n}=608)$

\begin{tabular}{lr}
\hline Naponta kétszer vagy többször & $348(57,24 \%)$ \\
Naponta egyszer & $186(30,59 \%)$ \\
Hetente 2-6 alkalommal & $25(4,11 \%)$ \\
Hetente egyszer & $27(4,44 \%)$ \\
Havonta 2-3 alkalommal & $6(0,98 \%)$ \\
Havonta egyszer & $3(0,49 \%)$ \\
Soha & $13(2,14 \%)$ \\
\hline
\end{tabular}

3. táblázat |A fogak tisztítására használt eszközök és kiegészítők $(\mathrm{n}=608)$

\begin{tabular}{lc}
\hline A fogak tisztítására használt eszközök & Populáció $(\mathrm{n}=608)$ \\
\hline Hagyományos fogkefe & $535(88 \%)$ \\
Elektromos fogkefe & $117(19,2 \%)$ \\
Fluoridtartalmú fogkrém & $540(88,8 \%)$ \\
Fogselyem & $77(12,7 \%)$ \\
Szájöblögető & $316(52 \%)$ \\
Fa fogpiszkáló & $221(36,3 \%)$ \\
Múanyag fogpiszkáló & $26(4,3 \%)$ \\
\hline
\end{tabular}

pótlására már nem fektettek hangsúlyt. A magyarországi átlagpopuláció DMF-T-számára vonatkozó felmérések 1985-ben (DMF-T: 15,8), 1991-ben (DMF-T: 15), 2000-ben (DMF-T: 15,7) és 2004-ben (DMF-T: 15,4) történtek [12-14]. Ha ehhez viszonyítjuk a rehabilitáció alatt álló betegek értékeit (DMF-T: 20,5), ezek szignifikánsan rosszabbak. Külföldön vizsgált specifikus betegcsoport (gerincvelősérültek) (DMF-T: 17,2) értékeinél is rosszabbak a hazai betegek értékei [15].

A páciensek magas százalékának fogeredetú fájdalmai nem voltak az elmúlt 12 hónapban, ez teljes mértékben ellentmond a felmért szájüregi állapotuknak.

A betegek számára a szájhigiénia fenntartásában hátrányt jelent a manuális funkciók csökkenése: a fogmosás kivitelezése önállóan nehezebb, a fogkefét nem tudják megragadni, megtartani [16]. A megfelelő szájhigiéniához szükséges kiegészító eszközöket nagyon kevesen tudják alkalmazni. Az előbb említettek következményeként nő a szájüregi plakk mennyisége, mely szuvasodáshoz, parodontalis betegségekhez és szájüregi fertőzésekhez vezethet [17]. A szájnyálkahártya-elváltozások fóként a rossz szájhigiénia és az ápolatlan fogpótlások miatt alakultak ki. A puhább állagú és magasabb szénhidráttartalmú ételek, melyeket a betegek nagy mennyiség- 
ben fogyasztanak, elősegítik a szuvasodás kialakulását [18]. Súlyosbítja a helyzetet az is, hogy a rehabilitáció alatt álló páciensek fogászati szürésen való részvétele nem kielégítő, így ezen páciensek fogászati problémái és szájnyálkahártya-elváltozásai is később vagy egyáltalán nem kerülnek kontroll alá. Elmondható, hogy az általunk vizsgált betegek több mint háromnegyede nem fogyaszt alkoholt, és nem dohányzik.

\section{Következtetések}

Megállapítható, hogy az általunk vizsgált, rehabilitáció alatt álló betegek dentális állapota kifejezetten rossz. Az ellátottság csupán alacsony szintjét figyelhetjük meg. A fogászati és szájnyálkahártya-elváltozások okozta panaszaik minimálisak az általános állapotukhoz képest, mivel a betegségeikre kapott erős fájdalomcsillapítók a fogeredetú fájdalmaikat is tompítják.

Vizsgálatunk eredményei rámutatnak arra a tényre, hogy a fogyatékkal élők, hátrányos helyzetük miatt, nehézségekkel küzdenek a megfelelő orális egészség kialakításában és fenntartásában, ezért speciális ellátást és kitüntetett figyelmet igényelnek. Ezen páciensek fogorvosi vizsgálatáról, ellátásáról, követésükről nem találhatók sem a külföldi, sem a magyar irodalomban irányelvek, protokollok.

Eredményeink segítségével, felmérve a helyzet súlyosságát, új fogászati prevenciós modellek létrehozását tervezzük, melyek elősegítik a páciensek megváltozott körülményeihez való alkalmazkodást. Így az egészségkárosodást szenvedett betegek önállóságukat visszanyerve kaphatnak lehetőséget a társadalomba való visszailleszkedésre.

Anyagi támogatás: A közlemény megírása anyagi támogatásban nem részesült.

Szerzői munkamegosztás: O. M.: A közlemény megírása. O. M., M. J.: A szűrővizsgálatok elvégzése. K. P.: A közlemény szerkesztése. N. O.: A folyamatok koordinálása és statisztikai elemzések. A cikk végleges változatát valamennyi szerző elolvasta és jóváhagyta.

Érdekeltségek: A szerzőknek nincsenek érdekeltségeik.

\section{Irodalom}

[1] Hungarian Central Statistical Office, 2011 Population Census, Disabled persons. [Központi Statisztikai Hivatal, 2011. évi népszámlálás - 11. Fogyatékossággal élő́k.] Központi Statisztikai Hivatal, Budapest, 2014. Available from: http://www.ksh.hu/ nepszamlalas/fogyatekossag_sb [accessed: March 2, 2018]. [Hungarian]

[2] World Health Organization. World report on disability. 2011 Available from: http://www.who.int/disabilities/world_report/2011/accessible_en.pdf [accessed: March 10, 2018].
[3] Vekerdy Nagy Zs. (ed.) Rehabilitation medicine. [Rehabilitációs orvoslás.] Medicina Könyvkiadó, Budapest, 2010. [Hungarian]

[4] Waldman HB, Perlman SP. Disability and rehabilitation: do we ever think about needed dental care? A case study: the USA. Disabil Rehabil. 2010; 32: 947-951.

[5] Széchenyi 2020 EU tender - Hungarian Government. The operational programs (2014-2020) accepted by the European Commission. [Széchenyi 2020 program. In: Az Európai Bizottság által elfogadott operatív programok (2014-2020).] https:// www.palyazat.gov.hu/az_europai_bizottsag_altal_elfogadott_ operativ_programok_2014_20 [accessed: June 30,2018]. [Hungarian]

[6] Institutes for special needs patients, by the Ministry of Human Capacities, Hungary. The 60/2003. (X. 20.) regulation by the Ministry of Health, Social and Family Affairs on the minimum requirements for providing health care services. [A 60/2003. (X. 20.) ESzCsM rendelet az egészségügyi szolgáltatások nyújtásához szükséges szakmai minimumfeltételekről.] http://www. meosz.hu/wp-content/uploads/2018/04/11-2-2018. 04.12EMMI-Eg\%C3\%A9szs\%C3\%A9g\%C3\%BCgyi-szolg\%C3\% Alltat\%C3\%AlsokSz\%C5\%Bl rvizsg\%C3\%Allatok-akad\%C3\%Al lymentes\%C3\%ADt\%C3\%A9se-v\%C3\%Allasz.pdf [accessed: June 30, 2018]. [Hungarian]

[7] Dénes Z, Fazekas G, Zsiga K, et al. Physicians' and medical students' knowledge on rehabilitation. [Rehabilitációs ismeretek kórházi orvosok és szigorlók körében.] Orv Hetil. 2012; 153: 954-961. [Hungarian]

[8] Marada Gy, Nagy Á, Sebestyén A, et al. Reimbursement of public dental care in Germany, the United Kingdom, Hungary and Poland. [A fogászati ellátás finanszírozása Németországban, az Egyesült Királyságban, Magyarországon és Lengyelországban.] Orv Hetil. 2016; 157: 547-553. [Hungarian]

[9] van Dommelen P, Schuller AA. The amount of care delivered: challenges of indices in oral health studies. Community Dent Oral Epidemiol. 2016; 44: 485-492.

[10] Oral Health Surveys: Basic Methods. 5th edn. WHO, 2013. Available from: http://www.who.int/oral_health/publications/9789241548649/en/ [accessed: March 10, 2018].

[11] MTA Cloud. [MTA Cloud.] https://cloud.mta.hu/ [accessed: March 8, 2018]. [Hungarian]

[12] Madléna M, Hermann P, Jáhn $M$, et al. Caries prevalence and tooth loss in Hungarian adult population: results of a national survey. BMC Public Health 2008; 8: 364.

[13] Czukor J. National Oral Health Pathfinger surveys in Hungary in the years 1985 and 1991. [WHO epidemiológiai vizsgálatok Magyarországon 1985-ben és 1991-ben.] Fogorv Szle. 1994, 87: 223-235. [Hungarian]

[14] Szőke J, Petersen PE. Oral health status of adults and elderly in Hungary. [A hazai felnőtt- és idős korú lakosság orális egészségi állapota az ezredfordulón.] Fogorv Szle. 2004; 97: 219-229. [Hungarian]

[15] Pakpour AH, Kumar S, Scheerman JF, et al. Oral health-related quality of life in Iranian patients with spinal cord injury: A casecontrol study. Injury 2016; 47: 1345-1352.

[16] Jeng WL, Wang TM, Cher TL, et al. Strategies for oral health care for people with disabilities in Taiwan. J Dent Sci. 2009; 4: 165-172.

[17] Kwok C, McIntyre A, Jansen S, et al. Oral care post stroke: a scoping review. J Oral Rehabil. 2015; 42: 65-74.

[18] British Society of Gerodontology. Guidelines for the oral healthcare of stroke survivors. 2010. Available from: https://www. gerodontology.com/content/uploads/2014/10/stroke_guidelines [accessed: March 20, 2018]

(Orsós Mercédesz dr.,

Budapest, Szentkirályi u. 40., 1088 e-mail: orsos.mercedesz@dent.semmelweis-univ.hu) 